REGULAR ARTICLE

\title{
EFFECTS OF SOME INSECTICIDES ON FORAGING HONEYBEES ON ONION FLOWERS UNDER FIELD CONDITION
}

\author{
DAWIT MELISIE ${ }^{*}$, TEBKEW DAMTE ${ }^{2}$
}

${ }^{1}$ Oromia Agricultural Research Institute, P. O. Box 85, Yabello,Ethiopia

${ }^{2}$ Ethiopian Agricultural Research Institute, P. O. Box 32, Debre zeit, Ethiopia

\begin{abstract}
In Ethiopia onion is an important condiment, vegetable and cash crop. Various insects attack the onion in fields, and is a major threat to onion cultivation. To overcome insect infestation problem, the use of different insecticides is a major controlling mechanism. However, the uses of these insecticides against insect pests have dangerous effects on beneficial insects like honeybees (Apis mellifera L.). In this investigation, we report insecticides effects on honeybees that forage on onion flower under field condition. Bombay red onion variety was used to assess the side-effects of profenofos 750 EC, lambda-cyhalothrin 5 EC, deltamethrin 2.5 EC, diazinon $60 \mathrm{EC}$, malathion $50 \mathrm{EC}$ and endosulfan $35 \mathrm{EC}$ at recommended rate on honeybees foraging on onion flowers. All the tested insecticides were found to be toxic to honeybees and caused mortality within $6 \mathrm{~h}$ after spraying.
\end{abstract}

\section{INTRODUCTION}

In Ethiopia onion is an important condiment, vegetable and cash crop. Even though onion is an important crop insect pest problem is one of the major constraints. Various insects like onion thrips, onion spider mite, lesser armyworm and western flower thrips are among the economically important ones (13). To overcome insect infestation problem, the use of different insecticides is a major controlling mechanism (10). The need for insecticides has been ever increasing, since most of injurious insects still cannot be held at lower level necessary to provide the high quality and damage free food and fibers. But the unforeseen effects are there with the use of many of the insecticides, most commonly the side effects on non-target organism like honeybees (Apis mellifera L.). This causes major problems and economic losses to beekeepers (9).

Honeybees are accepted as primary pollinators of most crops (7). The value of crops in U. S. A which got benefitted from pollination through honeybees approaches 20 billion dollar annually (10). In countries like Ethiopia, there are increase in crop yield with honeybee assisted pollination $(2 ; 1)$.

In Ethiopia the unintentional damage to honeybees through insecticide usage in crop plants decreased the pollination rates and thereby the crop production and also the honeybee colonies (3). Moreover, these insecticides have often resulted in conflict of interest between beekeepers and crop growers. Therefore, this study was undertaken to determine the level of toxicity at laboratory condition some widely used insecticides on honeybees that forage on onion flower

\section{MATERIALS AND METHODS}

\section{Raising onion plants}

Onion variety Bombay Red was obtained from Adami Tulu Agricultural Research Center and the bulb was planted on 28 October 2012 and the growing period was between 28 October 2012 and 12 March 2013, which favored flower stalk development, flowering and subsequent seed setting. A plot size of $3 \mathrm{~m} \times 3 \mathrm{~m}\left(9 \mathrm{~m}^{2}\right)$ was used for the experiment. On each plot, ridges of about $25 \mathrm{~cm}$ high were prepared at $50 \mathrm{~cm}$ interval. A single row of onion was planted per ridge and the spacing between plants was 30 $\mathrm{cm}$. The spacing between plots and between replications was $2 \mathrm{~m}$. Fertilizer was applied at a rate of $250 \mathrm{~kg} \mathrm{ha}$ ${ }^{1}$ diammonium phosphate (DAP) at the time of planting and $150 \mathrm{~kg} \mathrm{ha}^{-1}$ urea was applied $45 \mathrm{~d}$ after planting (12).

\section{Acute toxicity test}

The test insecticides were Deltamethrin, Diazinon, Endosulfan, Lambda-cyhalothrin, Malathion and Profenofos. These insecticides were purchased from Newaye P. L. C. (Addis Ababa) and Meki Farmers Union of Pesticide Distributor (Meki). The commercial rates recommended for controlling thrips is used for each insecticide in onion plants (table 1). For this experiment, randomized complete block design (RCBD) with three replications was used and insecticides along with untreated check were assigned randomly to the plots in a block.

Received 17 November 2017; Accepted 28 December 2017

${ }^{*}$ Corresponding Author

Dawit Melisie

Oromia Agricultural Research Institute, P. O. Box 85, Yabello, Ethiopia

Email: davemendu@gmail.com

(This article is open access and licensed under the terms of the Creative Commons Attribution License (http://creativecommons.org/licenses/by/4.o/) which permits unrestricted, use, distribution and reproduction in any medium, or format for any purpose, even commercially provided the work is properly cited. Attribution - You must give appropriate credit, provide a link to the license, and indicate if changes were made. 
Table 1: List of insecticides used for field tests on honeybees in Adami Tullu district in Ethiopia

\begin{tabular}{llll}
\hline Common name & Trade name & Rate (L/ha) & Spray volume (L) \\
\hline Deltamethrin & Ethiodemethrin 2.5\% EC & 0.11 & 917 \\
Diazinon & Ethiozinon 60\% EC & 0.50 & 1000 \\
Endosulfan & Ethiosulfan 35\% EC & 0.20 & 1000 \\
Lambda-cyhalothrin & Karate 5\% EC & 0.32 & 1000 \\
Malathion & Ethiolathione 50\% EC & 0.20 & 1000 \\
Profenofos & Selecron 750\% EC & 0.60 & 1200 \\
\hline
\end{tabular}

Six strong traditional hive colonies exhibiting good characteristics (gentleness, disease free and solid) were selected for the trial. The selected six colonies were strengthened through feeding and were placed at the experiment site two days before insecticide application on flowering onion. The colonies were kept untreated (i.e. no internal inspection) for two days prior to the application of the chemicals to familiarize them. The first insecticide application was made on 19 January 2013 when the onion was at $10 \%$ bloom and the second spray was made three days later (17).

\section{Data collection}

Each insecticide was sprayed at 8:30 am in the morning. Dead adult bees were first counted $3 \mathrm{~h}$ after treatment and continued for 4 and $6 \mathrm{~h}$ of the first day and 24 and $48 \mathrm{~h}$ of the next consecutive days. At each count, dead bees were removed from the plots.

\section{Foraging bees}

Number of living foraging honeybees was visually counted $1 \mathrm{~h}$ after spraying and was compared with the untreated plots. For each plot one person was assigned to count the number of visiting honeybees for $30 \mathrm{~min}$. Percent reduction over control was calculated using the formula (11).
Percent reduction overcontrol $=\frac{\text { Mean value of control }- \text { Mean valueof thetreatment }}{\text { Meanvalue of thecontrol }} \times 100$

\section{Seed yield of onion}

Onion seed yield was taken on plot base and converted to hectare then it was compared with untreated plot seed yield.

\section{RESULTS AND DISCUSSION}

Effect of insecticides on visiting honeybees on onion flower

All the tested insecticides had adverse effects on honeybees that visited onion flowers (table 2). As a result, there was more number of foraging honeybees in untreated onion flowers plot.

On the other hand, lambda-cyhalothrin, diazinon, deltamethrin, malathion and profenofos were more toxic/repellent and there were relatively less number of visitor honeybees than the number of bees in the control plot. The second spray was applied three days after the first spray. The number of flower visiting bees after the second spray was less than the number of visitor bees after the first spray. There was no significant difference among insecticides in terms of visiting honeybees but all were significantly different from the control treatment (table 3).

Table 2: Effect of insecticides on foraging honeybees on onion flower after the first spray in adami tullu jido kombolcha district in ethiopia

\begin{tabular}{lll}
\hline Insecticide & Mean number of visiting honeybees per plot & Reduction over control (\%) \\
\hline Deltamethrin & $11.33 \mathrm{~d}$ & 72.59 \\
Diazinon & $10.00 \mathrm{~d}$ & 75.80 \\
Endosulfan & $18.00 \mathrm{~b}$ & 56.45 \\
Lambda-cyhalothrin & $9.33 \mathrm{~d}$ & 77.43 \\
Malathion & $12.33 \mathrm{bc}$ & 70.17 \\
Profenofos & $12.67 \mathrm{bc}$ & 69.34 \\
Control & $41.33 \mathrm{a}$ & -
\end{tabular}

$\operatorname{LSD}(5 \%) 2.8$

CV (\%) 21.3

Means followed by the same letter within a column are not significantly different from each other at $5 \%$ probability level

Table 3: Effect of insecticides on visiting honeybees on onion flower after the second spray in in Ethiopia

\begin{tabular}{lll}
\hline Name of insecticide & Mean number of visiting honeybees per plot & Reduction of honeybees over control (\%) \\
\hline Deltamethrin & $4.67 \mathrm{~b}$ & 83.32 \\
Diazinon & $3.00 \mathrm{~b}$ & 89.29 \\
Endosulfan & $5.00 \mathrm{~b}$ & 82.14 \\
Lambda-cyhalothrin & $4.00 \mathrm{~b}$ & 85.71 \\
Malathion & $3.33 \mathrm{~b}$ & 88.11 \\
Profenofos & $4.00 \mathrm{~b}$ & 85.71 \\
Control & $28.00 \mathrm{a}$ & - \\
LSD (5\%) 3.75 & & \\
CV (\%) 28.40 & & \\
\hline
\end{tabular}

Means followed by the same letter within a column are not significantly different from each other at $5 \%$ probability level. 
This study showed that visiting of onion flowers by honeybees was affected by insecticide application. But, one time endosulfan sprayed plots had relatively greater number of visiting honeybees than on plots treated with other insecticides. This result is in agreement with the report by (4) who found that Endosulfan 35 EC was moderately toxic to honeybees than other insecticides used for that particular study. Similarly, (8) reported minimal hazards of Endosulfan $35 \mathrm{EC}$ to honeybees when applied under field conditions. However, lambda-cyhalothrin was repellant to honeybees under field condition and thus significantly reduced the number of flower visitor honeybees. According to (18), delthametrin had a repellant effect on honeybees lasting for 2-3 $\mathrm{h}$ and malathion is highly toxic to honeybees if it is exposed to direct treatment on blooming crops.

\section{Mortality of honeybees in insecticide sprayed onion}

There was a significant difference in the average number of dead honeybees in insecticide treated flowering onion table 4. All insecticides treated plots had significantly ( $\mathrm{p} \leq$ o.05) more number of dead honeybees than the control plot. Even though lambda-cyhalothrin treated-plots were visited by small number of honeybees, it caused the highest bee death $3 \mathrm{~h}$ after spraying, followed by diazinon and profenofos treated-plots, whereas relatively few numbers of dead bees were recorded on deltamethrin, malathion and endosulfan treated-plots. Dead bees were not found in the control plot.
Similarly, 4h after spraying, all insecticide treated plots had significantly high number of dead honeybees than the untreated check. The average number of dead bees in lambda-cyhalothrin, diazinon and malathion treated-plots was relatively more than the number of dead bees in endosulfan, profenofos and deltamethrin treated-plots. Six hour after spraying the insecticides profenofos, diazinon and deltamethrin caused significant death of honeybees as compared to control. The rest insecticides even though they caused death, they were not statistically different from the control.

According to (6) the estimated number of worker bees per colony is in between 10,000 and 80,000 . Therefore, the number of dead bees due to the effect of these insecticides at 4 and $6 \mathrm{~h}$ following treatments might not have significant influence on beekeeping. However, dead honeybees were not found in any of insecticides treated plots 24 and $48 \mathrm{~h}$ after spraying. Following the second insecticide spray on onion, the highest numbers of dead bees were found on lambda-cyhalothrin treated plots $3 \mathrm{~h}$ after spraying, whereas the lowest number of death was recorded in profenofos treated plots (table 5 ). However at the $4^{\text {th }}$ hours the highest number of dead honeybee was recorded in endosulfan sprayed plots and was lowest in deltamethrin treated-plots. The pattern of honeybees' death $6 \mathrm{~h}$ after spraying was similar to the $4^{\text {th }}$ hour death. As in case of first spray, there was no dead bee 24 and $48 \mathrm{~h}$ after the second spray.

Table 4: Mean number of dead honeybees in onions treated with different insecticides in Adami Tullu Jido Kombolcha District in in Ethiopia

\begin{tabular}{llll}
\hline Treatments & \multicolumn{2}{l}{ Number of dead bees after } & $\mathbf{6 h}$ \\
\cline { 2 - 4 } & $\mathbf{3 h}$ & $\mathbf{4 h}$ & $1.01(1.23) \mathrm{ab}$ \\
\hline Deltamethrin & $2.60(1.76) \mathrm{d}$ & $0.60(1.05) \mathrm{b}$ & $1.29(1.34) \mathrm{a}$ \\
Diazinon & $5.31(2.41) \mathrm{ab}$ & $1.63(1.46) \mathrm{a}$ & $0.60(1.05) \mathrm{abc}$ \\
Endosulfan & $2.99(1.87) \mathrm{cd}$ & $1.01(1.23) \mathrm{ab}$ & $0.60(1.05) \mathrm{abc}$ \\
Lambda-cyhalothrin & $6.31(2.61) \mathrm{a}$ & $1.63(1.46) \mathrm{a}$ & $0.27(0.88) \mathrm{bc}$ \\
Malathion & $2.96(1.86) \mathrm{cd}$ & $1.63(1.46) \mathrm{a}$ & $1.01(1.23) \mathrm{ab}$ \\
Profenofos & $3.95(2.11) \mathrm{bc}$ & $1.01(1.23) \mathrm{ab}$ & $0.00(0.71) \mathrm{c}$ \\
Control & $0.00(0.71) \mathrm{e}$ & $0.00(0.71) \mathrm{c}$ & 0.39 \\
LSD (5\%) & 0.34 & 0.29 & 21.1 \\
CV (\%) & 10.1 & 13.3 & \\
\hline
\end{tabular}

Numbers within parenthesis are values transformed to square root scale, Means followed by the same letter within the column are not significantly different from each other at $5 \%$ probability level

Table 5: Mean number of dead honeybees in onions treated with different insecticides after the second spray in Adami Tullu Jido Kombolcha District in in Ethiopia

\begin{tabular}{llll}
\hline Treatments & \multicolumn{2}{l}{ Number of dead bees after } & $\mathbf{6 h}$ \\
\cline { 2 - 4 } & $\mathbf{3 h}$ & $\mathbf{4 h}$ & $0.00(0.71) \mathrm{c}$ \\
\hline Deltamethrin & $1.59(1.44) \mathrm{bc}$ & $0.60(1.05) \mathrm{bc}$ & $1.29(1.34) \mathrm{a}$ \\
Diazinon & $1.99(1.58) \mathrm{ab}$ & $2.32(1.68) \mathrm{a}$ & $1.29(1.34) \mathrm{a}$ \\
Endosulfan & $1.29(1.34) \mathrm{bc}$ & $2.63(1.77) \mathrm{a}$ & $0.87(1.17) \mathrm{ab}$ \\
Lambda-cyhalothrin & $2.63(1.77) \mathrm{a}$ & $2.42(1.71) \mathrm{bc}$ & $0.27(0.88) \mathrm{bc}$ \\
Malathion & $1.29(1.34) \mathrm{bc}$ & $1.63(1.46) \mathrm{ab}$ & $0.27(0.88) \mathrm{bc}$ \\
Profenofos & $1.01(1.23) \mathrm{c}$ & $0.87(1.17) \mathrm{bc}$ & $0.00(0.71) \mathrm{c}$ \\
Control & $0.00(0.71) \mathrm{d}$ & $0.00(0.71) \mathrm{c}$ & 0.34 \\
LSD (5\%) & 0.32 & 0.47 & 20.3 \\
CV (\%) & 13.3 & 20.4 & \\
\hline
\end{tabular}

Numbers within parenthesis are values transformed to square root scale, Means followed by the same letter within the column are not significantly different from each other at $5 \%$ probability level 
Table 6: Seed yield of onion as influenced by insecticides effects on pollinators in Adami Tullu Jido Kombolcha District in 2012/13

\begin{tabular}{ll}
\hline Insecticides & Mean seed yield (kg/ha) \\
\hline Deltamethrin & $889 \mathrm{c}$ \\
Diazinon & $1074 \mathrm{bc}$ \\
Endosulfan & $1000 \mathrm{bc}$ \\
Lambda-cyhalothrin & $1148 \mathrm{abc}$ \\
Malathion & $1037 \mathrm{bc}$ \\
Profenofos & $1259 \mathrm{ab}$ \\
Control & $1481 \mathrm{a}$ \\
LSD (5\%) 335.0 & \\
CV (\%) 16.7 & \\
\hline
\end{tabular}

Means followed by the same within the column letter are not significantly different from each other at $5 \%$ probability level

The tested insecticides caused different levels of honeybee mortality $3 \mathrm{~h}$ after the first spray was made. In this study, diazinon and lambda-cyhalothrin were more toxic to honeybees than the other insecticides. According to (15), diazinon is classified by US Environmental Protection Agency (EPA) Office of Pesticide Programs as "highly toxic" to honeybees and also shortens the life span of worker honeybees. Similarly, when honeybees were exposed to lambda-cyhalothrin during field application, it caused significant mortality. Though lambda-cyhalothrin had a repelling effect, those bees that visited the sprayed flowers might have died from direct contact with the insecticide. On the other hand, malathion, deltamethrin and endosulfan were less toxic to honeybees although the report of (16) indicates that malathion is highly toxic to bees, whether from direct contact, contact with foliar residues, or contact with residues on pollen. This difference might have occurred due to the difference in the studied honeybee race. In field studies, deltamethrin did not harm bees (18) and (14) in field experiments found that endosulfan is less toxic insecticide against honeybees.

\section{Effects of honeybee on onion seed yield}

There was significant difference $(\mathrm{p}<0.05)$ in seed yield among onions treated with different insecticides (table 6). The control, i.e., insecticide untreated plot out yielded all insecticide treated onions. Among insecticide treated onions, profenofos or lambda-cyhalothrin sprayed onions gave greater seed yield than the other insecticides. The lowest seed yield was obtained in deltamethrin sprayed plot. The exact reason why lambda-cyhalothrin treated onions gave better seed yield, despite the high mortality of foraging honeybee, is unknown. However, since the study was done under natural environment, other pollinators might also have been involved in the pollination of onions. Nevertheless, if honeybees were involved in pollination, the yield would have been much greater than in insecticide sprayed condition (1). This is because use of insecticides results in repellence or killing of honeybees, thus reducing the crop yield (5).

\section{Conclusion and recommendation}

From this study it can be concluded that all field-tested insecticides at the recommended rate were toxic to honeybees and had indirect effects on onion seed production. Therefore, from the current study the following recommendation were drawn all tested insecticides should be applied during night time when bees are not active; farmers should apply other pest control options, like IPM which uses lesser chemicals; there should be a policy that enforces the crop growers using these chemicals to aware the beekeepers nearby at least a day before insecticide applied; and there is a need for further research on these insecticides to determine inside hive effects of Ethiopian bee races.

\section{REFERENCES}

1. Admasu Addi, Gizaw Ebsa, Amsalu Bezabih, and Debisa Lemessa. 2006. Effect of honeybee pollination on seed of Allium cepa. Holeta Bee Research Center, Holeta $11 \mathrm{pp}$

2. Admasu Addi and Nuru Adgaba. 2000. Effect of honeybee pollination on seed yield and oil content of Niger (Guizotia abyssinica): pp. 67-73. In Proceedings of the First National Conference of Ethiopian Beekeepers Association, June 7-8, 1999, Addis Ababa, Ethiopia

3. Amssalu Bezabeh, 2010, Toxicity effects of commonly used agro-chemicals to Ethiopian honeybees, Unpublished, Hololta Bee Research Center, Holota $13 \mathrm{pp}$

4. Anderson, L. D. and Atkins, E. L. Jr. 1968. Pesticide usage in relation to beekeeping Annual. Review. Entomology., 13:213-238.

5. Haq, M. and Gardezi, T. H. 1983. A comparative study on the toxicity of organophosphorus insecticides to honeybees. Pakistan Entomology, 5:83-87.

6. HBRC. (Holeta Bee Research Center). 1997. Beekeeping Training Manual (unpublished), HBRC, Holeta, Ethiopia. 207 pp.

7. James, R. Hagler, Gordon D. Waller and B. E. Lewis. 1989. Mortality of honeybees (Hymenoptera: Apidae) exposed to permethrin and combinations of permethrin with peperonyl butoxide, Jaurnal of Apicultural Research 2894:208-211.

8. Johansen, C. A. 1977. Pesticides and pollinators. Annual Review Entomology. 22:177-192.

9. Kamara, A. Y., I. A. Teli, and I. Y. Dugje. 2004. Draft report of technical training course on pest control principles and methodologies for contract sprayers, agrochemical dealers, extension agents and lead farmers organized by PROSAB, 1-11 September 2004. 78 pp.

10. Levis, M. D. 1970. The effect of pesticides on beekeeping in the United State, American Bee Journal 110 : 8-9

11. Mahi. I., Mahbubar. R and Zinnatul. A., 2012, Toxic Effect of Some Insecticides on Predatory Lady Bird Beetles (Coleoptera: Coccinellidae) in Country Bean (Lablab purpureus L.) Field, Bangabandhu Sheikh Mujibur Rahman Agricultural University, Bangladesh World Journal of Zoology 7 : pp. 347-350

12. Olani Nikus and Fikre Mulugeta, 2010 Onion Seed Production Techniques; Manual for Extension Agents and Seed Producers, Asella, Ethiopia, pp. 112 pp.

13. PPSE (Plant Protection Society of Ethiopia). 2009. Abraham Tadesse (ed) Increasing crop production 
through improved plant protection, Volume II Addis Ababa, Ethiopia pp.542

14. Singh, P. B., D. S. Singh, M. Naim and V. S. Srivastava, 1997. Contact toxicity of some insecticides to oriental honeybee, Apis cerana indicaforagers. Annual Plant Protection Society 5:207-9.

15. Smirle, M. J. M. L. Winston, and K. L. Woodward., 1984. Development of a sensitive bioassay for evaluating sublethal pesticide effects on the honey bee (Hymenoptera: Apidae). Journal of Economic Entomology 77:63067
16. Tomlin, C. D. S., 2006. The Pesticide Manual, A World Compendium, 14th ed.; British Crop Protection Council: Alton, Hampshire, UK; pp 643

17. Voss R. E. 1979. Onion production in California Leaflet No. 4097. 22 pp. Anderson, L. D. and Atkins, E. L. Jr. 1968. Pesticide usage in relation to beekeeping Annual. Review. Entomology., 13:213238.

18. WHO (World Health Organization) 1990. Environmental Health Criteria 97-Deltamethrin; International Programme on Chemical Safety, World Health Organization: Geneva, Switzerland; 133 pp. 